\title{
Conducting Law Pedagogy Using Virtual Classroom in the Era of COVID-19 Pandemic: Opportunities and Existing Obstacles
}

\author{
Kolawole Sola Odeku
}

\author{
Faculty of Management and Law,
} University of Limpopo, South Africa

DOI: https://doi.org/10.36941/jesr-2021-0011

\begin{abstract}
Globally, the coronavirus (COVID-19) pandemic is disrupting the way of life, affecting not only humans' health, but also the education sector and law pedagogy is no exception. In South Africa, before the COVID-19 pandemic, most pedagogies at the universities were being conducted face-to-face. The pandemic has inadvertently exposed the strengths and weaknesses of university in conducting pedagogies. Consequently, various educational institutions became creative, using their ICT staff to train teaching staff members on how to use various multi-modal technologies and devices to conduct pedagogy as face-to-face pedagogy is restricted. Law lecturers who pride themselves in conducting pedagogies through face-to-face were also coopted and retrained considering that most of the law lecturers are broadly conservatives and not technologically savvy. There is paucity of any scholarly information from law as a discipline hence, this paper fills the lacuna by looking at law pedagogy in the era of COVID-19 pandemic.
\end{abstract}

Keywords: COVID-19 pandemic, Educators, New normal, Virtual classrooms, Blended pedagogy, University of Limpopo

\section{Introduction}

Law profession is essentially unique because a person for a law degree requires intensive teaching and learning in order to acquire the requisite skill and competency to function and work as a lawyer (Mertz, 2007). One of the motivating and intriguing aspects of law pedagogy is when a law lecturer demonstrates to law students in an in-personal face-to-face classroom setting what is expected of a law student using different methods of pedagogies to explain the rudiments of the subject and sometimes conducting presentations and moot courts (Oduwole, 2012). This is the reason why in law pedagogy, venue-based pedagogy is often encouraged and preferred to ensure that students are being taught in a manner that will enhance both their contextual understanding of the law and the competencies needed to become a successful lawyer (Häkkinen et al., 2017). Furthermore, face-to face pedagogy provides better opportunity for the lecturers to observe if a student is not grasping a concept or lack confidence to express the lack of understanding (Price et al., 2007). Gestures like a slow nodding of the head accompanied by a smile might be a confirmation that the students understand the topic and that learning is taking place (Helmer et al., 2003). As such, they are then able to devise or take an alternative approach to explaining the topic to the struggling student before progressing and continuing pedagogy 
(Florian and Linklater, 2010).

Undoubtedly, while face-to-face is often the preferred and orthodox approach of delivering pedagogy to law students, COVID-19 pandemic has changed the pedagogy environment and brought a new normal pedagogy. Law lecturers need to face the reality because the pedagogic landscape and environment are not static, they have changed tremendously. They keep evolving and presently, the use of technology for pedagogy is in vogue and the in-thing. Against this backdrop, law lecturers have to respond to and embrace technology for effective and efficient pedagogy during and post COVID-19 pandemic crisis.

Undoubtedly, there is need for prompt reflexes to survive by thinking out of the box and take necessary steps in the right direction and navigate through the uncertainty and crisis. The COVID-19 pandemic outbreak had hit very hard on all aspects of human endeavors by interrupted many dimensions of our lives and education sector is no exception. As part of the strategies to navigate the crisis, multi-modal pedagogies are now the new normal during the lockdowns, most of the pedagogies were being conducted online. Although there is concern of whether universities in South Africa were adequately equipped to deploy and use technological tools for pedagogies as well as the curriculum. Another concern was whether lecturers have the know-how, knowledge and skills needed to engage effectively in distance education and to implement pedagogies of care, and attend to students' affective needs during the pandemic. While these are legitimate concerns, it is pertinent to point out that government and the Department of Higher Education working together with the universities have provided, to a larger extent, assistance and supports that the universities would need to achieve pedagogies during the lockdowns and it is expected that post-pandemic, this shall continue unabated. Hence, there seems to be plethora of terms generally used interchangeably to describe the online technological tools "such as distance education, e-learning, blended learning, online learning, online teaching, remote teaching, virtual learning" (Mbunge, 2020). Regardless of the terms or names, what is important is that these technological intervention tools make pedagogies possible and easier in the times of critical needs such as the manifestations of the COVID-19 pandemic outbreaks with different impacts and effects.

The highly contagious nature of the novel coronavirus which currently has no cure has prompted most countries to put in place safety measures to slow down the spread of the virus. Consequently, social isolation, handwashing, wearing of face marks and social distancing measures were introduced to curb the spread of the virus which also disrupted school-based education in most countries around the world (Reimers, 2020). As a matter of fact, globally, many educational institutions closed and pedagogy stopped for a while. However, the institution leaderships due to the imperative to attend to the educational needs of children and youth during the COVID-19 crisis (Reimers, 2020), had a paradigm shift and began introducing various multi-modal online teaching methods (Jewitt et al., 2016). Evidently, the pandemic has forced learning institutions, including universities to devise means of conducting pedagogies through virtual multi-modal (Kirschner, 2020). Virtually all universities are now required to embrace the new normal by switching to the new e-learning platforms (Wilson, 2020).

Higher institutions have now introduced broadly educational technology for pedagogy (Jaffer et al., 2007). Educational technology uses a systematic application of relevant technological processes and resources for pedagogy with the aim and objective of improving students' performance (O'Flaherty and Phillips, 2015). The system uses a disciplined approach to identifying the needs of students, applying technology in instructions and tracking their performance (Laurillard, 2013). University of Limpopo has adopted educational technologies of different types to conduct pedagogies in and outside the University. Irrespective of the discipline or module, educational technology is now being used to conduct the pedagogy. Lecturers have been enjoined to tailor their pedagogic activities in line with the various pedagogical technologies in place. And more importantly, it is important to point out that these educational technologies and the resources provided by the university are relevant to the curriculum goals and milestones. One of the requirements of the educational technology is to ensure that lecturers approach pedagogy based on the discipline approach in order to meet the needs of the students (Malik and Agarwal, 2012). This is the reason why the University introduced trainings and 
workshops to train, retrain and empower lecturers in order to know how to use technology to meet all needs of modern law students (Hefzallah, 2004).

It is pertinent to point out that previous generations of law students used colorful hard copy textbooks usually sourced from the university law library or purchased from the bookshops for their law studies and venue-based classrooms pedagogy (Callister, 2003). Modern day law students now need contemporary technology for pedagogy because most of them now engage with technology in and outside the classrooms on a daily basis (Lasso, 2002). Modern law students are technologically savvy, they use internet and different devices ranging from laptops, smartphones and tablets for all activities including pedagogy (Burden et al., 2019). Law lecturers have to be sensitive and respect the inclination and use it to their advantage because the use of technology resonates perfectly well with the modern-day students where they engage productively during technological pedagogy (Lee et 1., 2012). These days, university requires law lecturers to take the responsibility of making law students to be responsible digital citizens (Choi et al, 2018).

These educational technology interventions make pedagogy to be very flexible and adaptable during the COVID-19 pandemic. According to Huang et al., (2020) "flexibility is defined as offering choices in the educational environment, as well as customizing a given course to meet the needs of individual learners. Therefore, providing the possibility of making learning choices to learners is crucial. These learning choices can cover class times, course contents, instructional approach, learning resources and location, technology use, the requirements for entry/completion dates, and communication medium." However, as this has not been the norm in most universities, virtual mode of teaching may impact on the effectiveness of teaching and learning, especially subjects/modules that may require physical participation. The overall objective of this paper is to showcase how universities, particularly the University of Limpopo has stepped up to today's challenges confronting higher institutions in using educational technologies of all types to conduct pedagogy to law students and more importantly in the midst of COVID-19 pandemic outbreak. It explains that post COVID-19 pandemic, the University will continue to use multi-modal for pedagogies because of their numerous opportunities to the law lecturers, students and the University.

In South Africa, prior to the COVID-19 pandemic outbreak, in most institutions, the primary mode of pedagogy was venue-based face-to-face, the pandemic has changed the pedagogic landscape and its environment. With regard to flexibility, provided a student has an access to internet connectivity and a computer, even if the student is in remote rural area, the student would be able to access online learning easily. What is required is a laptop and data which are easily provided by most Historically Black Universities to students, University of Limpopo championed this by giving laptops and data to the students including lecturers so that pedagogy can continue amid the pandemic.

Online pedagogy is considered to remove the hassles of transportation, accommodation, and the overall cost of institution-based learning that students are used to. Flexibility is profound to the extent that students can have scheduled or planned time for pedagogy, assessment and time to complete the courses. Another positive aspect of the online pedagogy is that students can learn anytime and anywhere convenient to them (Potts, 2019). Online learning also presents opportunities to develop competency in computer and other new skills which will make the students become employable (Dhawa, 2020).

\section{Methods}

The methods utilized to conduct this research were search, critical review and application of existing literature on COVID-19 pandemic, its ravaging impacts and effects on educational sector and in particular law pedagogy in the era of COVID-19 pandemic in South Africa (Mahaye, 2020). The paper is theoretical in nature. As such, secondary data was used to examine the implementation, use, advantages and challenges of innovative educational technology tools and in particular virtual tool for pedagogy classrooms at the University in South Africa during the pandemic lockdowns. 


\section{Literature Review}

Notwithstanding the COVID-19 pandemic, the world cannot be on lockdown permanently (Kuguyo et al., 2020). Bearing this in mind, educational institutions cannot be closed forever as education is key in life. In the same vein, in an effort to contain the spread of the COVID-19, South African government announced the nationwide lockdowns including the closure of all educational institutions from crèche to tertiary university education for 21 days from midnight on Thursday March 262020 in a bid to contain the spread of the deadly COVID-1o pandemic outbreak in order to save lives of hundreds of thousands of South Africans (Doyle, 2020). The nation's lockdown was a non-pharmaceutical measure used in South Africa just like many countries to curb the spread of the virus. Undoubtedly, the lockdown is generally recognized in the medical fraternity to be one of the effective forms of mitigating the transmission of the virus. Although the lockdown has huge social and economic implications, the action taken by the government was regarded as the right thing to do (Al Lily et al., 2020). One of the lockdown implications is that pedagogy has shifted from the classrooms to the homes of students (Azevedo et al., 2020).

The lockdowns provided opportunities for lecturers, university administrators and management to offer various academic supports to the students by reaching out to them by compassion care, encouragement, to stay safe and healthy, sharing anxieties, and working together to make sure that assignments are completed, and courses finalised during these unusual times. These supports were given considering the fact that emotions and relationships form the basis of every successful pedagogy. These supports are imperatives especially when the majority of the students are from humble and poor backgrounds (Cornelius-White and Harbaugh, 2009). The communities, families of the students relied solely on the access to the university for all their educational needs in terms of laptops, devices, electronic communications and other relevant material resources that the university will provide them to receive high quality pedagogy which would make them competent and get placement, be employed and escape and overcome poverty.

Even though the pandemic is scary and deadly, it has brought out the best in human beings. In the university, both lecturers and students have been working together by supporting each other, sharing anxieties and feelings; listening to each other's stories in order to stay alive and at the same time continue pedagogy online. Lecturers have displayed high levels of professionalisms and expertise during these trying times and this is commendable.

University of Limpopo epitomizes located in rural area called Turfloop in the Limpopo Province in South Africa is one of the universities that is embracing modern-day technology to conduct and deliver blended pedagogy to its numerous lecturers and students even prior the COVID-19 pandemic, it has now widened the cope by deploying broadly educational technological tools during the outbreak for academic support to the lecturers and students in these trying times and crisis. According to Hamad (2017), a blended pedagogy "is an educational program (formal or informal) that combines online digital media with traditional classroom methods requiring the physical presence of both teacher and student, with some element of student control over time, place, path, or pace. While students still attend brick-and-mortar schools with a teacher present, face-to-face classroom practices are combined with computer mediated activities regarding content and delivery. Blended learning is also used in professional development and training settings."

One of such online platforms is the Blackboard. Blackboard is a web-based learning management system used by schools all over the world for instructing, interacting and assessing students online (Sife et al., 2007). It is a program/software built to enhance teaching methods and the learning processes of students (Dokur, 2008). It is very conducive to use as it is open, flexible, and centered on student achievement (Zawaidy, 2014). University of Limpopo has adopted this technology as the most potent for its broad pedagogy in and outside of the university. Law lecturers have been trained in order to empower them to use it to provide and deliver contemporary competent based pedagogy to all law's students.

The use of blackboard resonates with the United Nations Educational, Scientific and Cultural 
Organization (UNESCO) enjoins the international community to pay attention to the issue of Education Response in Crises and Emergencies. UNESCO stated in the Education 2030 Incheon Declaration and Framework for Action that countries should "provide alternative modes of learning and education for children and adolescents who are not in school at both the primary and secondary levels, and put in place equivalency and bridging programmes, recognized and accredited by the state, to ensure flexible learning in both formal and non-formal settings, including in emergency situations."

Blackboard is now being used extensively at the University of Limpopo due to its flexible use for teaching and learning anywhere provided one has a laptop and internet connectivity. Backboard pedagogy is a student-centered, innovative, and flexible tool to use by both the student and the lecturer (Dhawan, 2020). As such, the uniqueness of the Blackboard as an aspect of e-learnings is that students can learn anywhere on their own independently and at the same time interact and engage with their lecturers and other students. Using online-blackboard for synchronous pedagogy is impetus for engagement and social interaction during this pandemic considering the virus is deadly and its spread needs to be curbed. Hence the need for online platforms are imperatives as recorded lecture videos can be shared with the students, and there is always instant feedback to the students whenever assignments have been submitted by students to the blackboard (Dawan, 2020). The development of information and communication technologies have led to new learning approaches and modes. It has also opened more opportunities for flexible pedagogy which is one of the imperatives using open learning which is a method of studying that allows students to learn wherever they are and when they want to and at the same time to receive and send written work by mail or email (Sheail, 2018). Online learning makes students to be more self-determined and independent, and at the same time makes lecturers become effective in their pedagogy (Huang et al., 2020). It is apparent that physical class attendance considered to be a barrier especially during COVID-19 pandemic outbreak is removed so that students can still learn even though the virus is not yet contained and curtailed (Huang et al., 2020).

The pandemic has now made online pedagogy well entrenched and widely embraced by the university community. There is need to point out that initially, there was a serious hurdle in getting lecturers to learn and adapt to using the online-blackboard system because change is difficult, especially for old-fashioned lecturers. Most never imagined that there would be any reason for them to switch to using new technology as a teaching tool. The University of Limpopo became helpful by using their ICT staff as an educational innovation team to provide voluntary training to lecturers through multiple training in quick successions. The attendance on a daily basis was very encouraging and the facilitators used simplistic methods to deliver the training using pictograms and videos.

In order to access and get connected to the Blackboard, the first step is to send an email to the ICT section of the University to set up Blackboard for the module the lecturer is teaching, say for an example, Development Law-CDLA 191. Thereafter, the ICT will set it up and issue username and password with strict instruction that the email should not be deleted but kept as future reference. Thereafter, if the lecturer needs training for purposes of conducting pedagogies on the newly created Blackboard, the lecturer responds to the training notice issued by the ICT to register and receive online training on how to use Blackboard. After registration, the Blackboard Learn Training-Online Assessment is sent to the lecturer. The manual was designed by the training sector of the ICT department. The significance of the manual is that it details each step to take to operate the Blackboard for pedagogies. More importantly, Image 1, reflects the left side written Blackboard-this is the panel where all activities are being conducted and consists of the home page, course materials, submission of the module to the Blackboard, course tools, post submission of assignments, submission of assignment scripts and so on. 


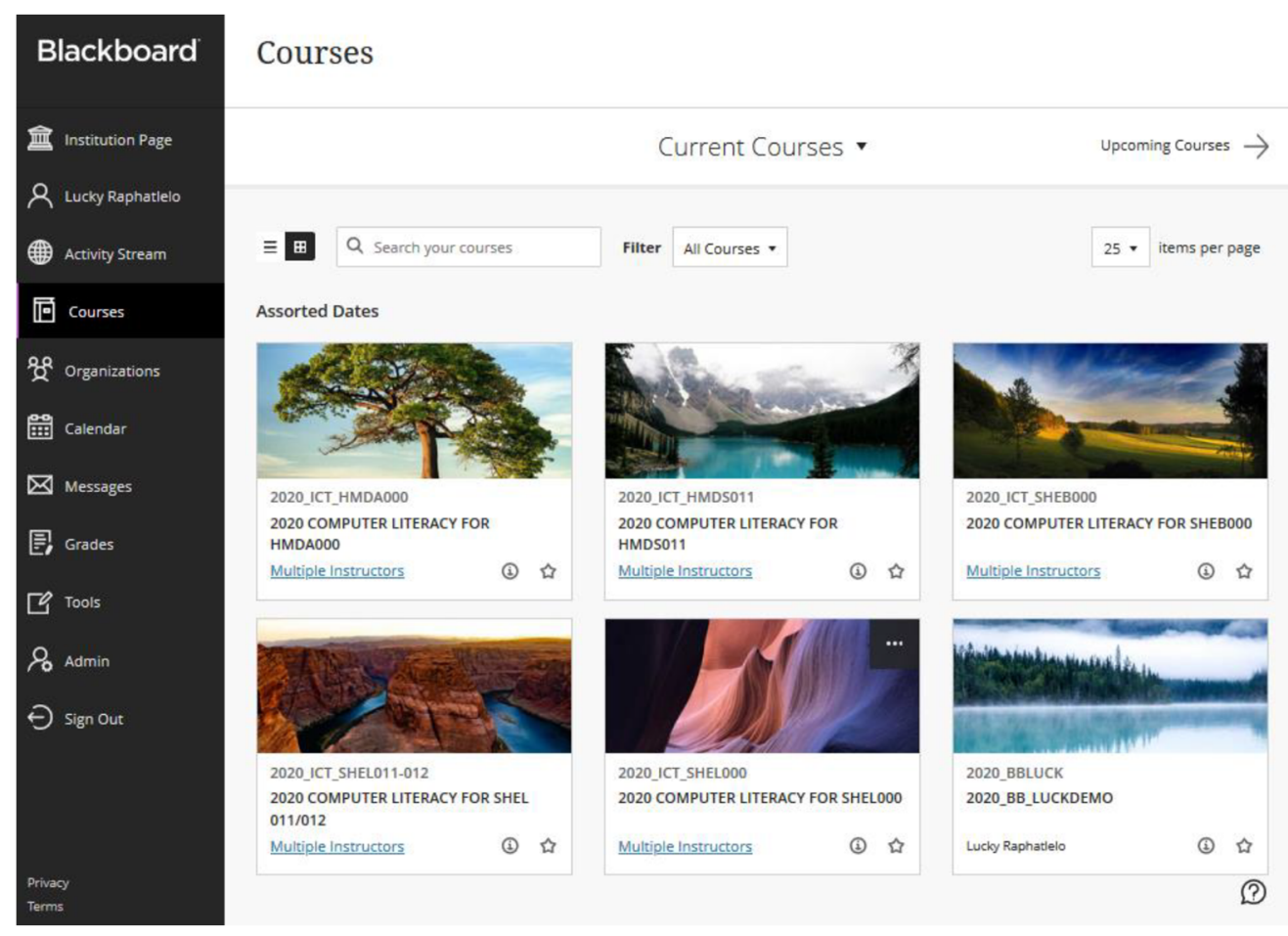

Image 1. Prepared by Mokgokong C, Boshielo, A. and Raphatlelo, L. (2020). Blackboard Learn and Training, University of Limpopo, South Africa.

Furthermore, the University partnered with one of the leading local telecommunications companies to provide data to both students and lecturers at the expense of the University. The University installed and provided lecturers with $3 \mathrm{G}$ Wireless Technology which is "the third generation of wireless technologies. It comes with enhancements over earlier wireless technologies, such as high-speed transmission, advanced multimedia access, and global roaming. ${ }_{3} \mathrm{G}$ is mostly used with mobile phones and handsets as a means to connect the phone to the internet or other IP networks in order to make voice and video calls, to download and upload data, and to surf the Web" (Unuth, 2020). While students were each given 30 GB data after the COVID-19 pandemic outbreak in order to access internet for pedagogy. It is pertinent to point out that most students are technologically savvy-they have been trained on how to use the Blackboard as a learning tool thus making it easier for pedagogy to be conducted virtually. However, the major challenge faced by the students was the incessant nationwide electricity outages commonly referred to as "load shedding." This caused setbacks as students are often unable to charge their computers for use when needed and access to internet connectivity is also affected during load shedding impacting on pedagogy.

Despite the support and efforts by the institutions and South African government to continue teaching and learning virtually, there are still various challenges due to virtual learning that might impact on education.

\section{Challenges being Encountered as a Result of Virtual Pedagogy During COVID-19 Pandemic}

The lockdowns, coupled with the educational institution closures have resulted in thousands of students being excluded from the normal learning process in South Africa (Parker et al., 2020). It is 
pertinent to point out that most university lecturers have to stay at home and deliver pedagogy online. While some of the lecturers are technologically savvy, many of them were faced with challenges of not being acquainted to the new learning platform. As a matter of fact, despite the training offered by the university of Limpopo, many university lecturers are still struggling to grapple with the new technology. As such, they prefer to continue to use old-fashioned model like face-to-face method for delivering pedagogy, depriving the students' modern-day technological inclusive pedagogy being used to enhance the competency of the students. Of note, even post COVID-19 pandemic, as part of the educational transformative agenda of the government of South Africa, technology and innovations take the front row and as such, should be prominent in all aspects of pedagogies in all universities. This will enrich competency, make the students technologically savvy and will fulfil the aspect of government educational transformation agenda to wit; pedagogy for employability (Huang et al., 2020).

Online virtual pedagogy is bedeviled with both physical and non-physical challenges such as owning a device for the purpose of accessibility to internet; in this situation, the student has the requisite devices for technology but lack internet connectivity and as such unable to use the device for the desired purposes. There are also the time constraints where the students are unable to meet up with the time set by the lecturers to conduct pedagogy due to socio-economic challenges such as overcrowded one room being used by the whole family. There is also the challenge of affordability in the sense that internet and other devices are viable but the student lack the requisite finial capacity and capability to afford them. More importantly is the psychological conditions of the student especially socio-economic conditions where the student lives in abject poverty without access to any educational financial assistance to afford educational technologies and devices to be used for pedagogy. In South Africa, electricity access especially for indigent students in remote isolated rural areas is a serious challenge hence depriving them the opportunity to use electricity to charge and power their educational technological tools even if they have them. Educational devices are very expensive and as such attracted to thieves who would do everything to steal them from the students and sell them for peanuts.

It is important to stress that various educational technological devices and systems that are being deployed for pedagogy at the University are very important but most of them are complicated and how to effectively and efficiently use them need to be properly explained to the students and lecturers otherwise they become useless in the possession of students and lecturers (McLoughlin and Lee, 2007). To address this problem, the University of Limpopo management being the leadership had intervened to train, skill and empower both lecturers and students on how to handle and use these devices for effective and efficient pedagogy. This is the reason why the university has deployed substantial resources into training needs that lie ahead of education systems to get ready for educational technology (Bakker and Wagner, 2020). However, while this university intervention is apt, Bakker and Wagner (2020) admonished that "inequality and the digital divide will only increase, because many students do not have the resources and opportunities to engage in online education. With millions of people suddenly using online platforms, crashing software or poor access is all too common." This is notable inequality and as such, providing technological devices to poor indigent students living in the rural remote areas is not the panacea that will enable them to study in conducive serene environment (Doyle, 2020). Imagine a family of 13 people living in a room. How can a student study in such an environment without being disturbed? Certainly, high level of inequality in South Africa is a set back and major concern. COVID-19 pandemic has exacerbated the dire living conditions of the poor, marginalized and indigents socio-economically disadvantaged students in South African. This will continue to impact the quality of education being received during COVID-19 crisis regardless of the assistance and resources that have been made available (Bramble, 2020). The pedagogy environment has to be conducive at all times in order satisfy the educational transformative agenda of the South African government which seeks to priorities access to high quality standard education, but not the other way round (Badat, 2010). 


\section{Virtual Classroom Pedagogy in the Era of COVID-19 Crisis}

In South Africa, at the beginning of the COVID-19 lockdown, all aspects of face-to face pedagogies were cancelled by the government in order to contain the spread of the deadly virus and save hundreds of thousands of lives (Yandell, 2020). Currently, evidence indicate that mitigation measures and interventions introduced to slow the spread of the virus are producing positive results as the rates of infections continue to decrease (Piguillem and Shi, 2020). To this end, government and most universities have now introduced a combination of face-to-face and virtual pedagogy giving rise to blended pedagogy and flipped classrooms (Hamad (2017). TeachThought (2020) defines a flipped classroom as a "type of blended learning where students are introduced to content at home and practice working through it at school. This is the reverse of the more common practice of introducing new content at school, then assigning homework and projects to completed by the students independently at home." These measures have now increased and added immense values to the learning environments and contributed immensely to the learning potentials of the students using combined blended pedagogies.

Online pedagogy is able to take place in a synchronous or asynchronous learning environments (Yamagata-Lynch. 2014). In a synchronous learning environment is where pedagogy is scheduled and being conducted at the set time. Both students and the instructors have instantaneous or immediate real-time interactions at an agreed time which have the potential to help students stay on track and manage their time (Francescucci and Foster, 2013). In an online pedagogy, "students can use the online learning content that they find in multiple formats (e.g., video, audio, document, etc.) for learning in different ways with different objectives. Additionally, they can also choose the learning pace according to their own need, by directing and evaluating with the assistance of a teacher. This interaction can take place within a community of inquiry, using a variety of internet-based synchronous and asynchronous activities (video, audio, computer conferencing, chats, or virtual world interaction). These asynchronous and synchronous online environments could promote the development of social and collaborative skills, as well as personal relationships among participants" (Huang et al. 2020). The Blackboard Collaborate is one of the perfect examples of a synchronous tool being used to conduct online pedagogy. Blackboard collaborate presents ample opportunity for the class to meet for purposes of delivering pedagogy to the student (Bower, 2014). It is an effective tool for virtual classroom, for electronic examination, for assignments, for course messages and discussions all in the quest to get the best desired pedagogic outcomes (Hamad, 2017). In addition, collaborate can also be used for the office hours and study sessions, have impromptu discussions, and host guest speakers.

To continue the facilitation and delivery of pedagogy at the university, lecturers have been enjoined to utilize flexible instructions in order to ensure that the quality of pedagogy during this pandemic is maintained. This requires the use of flexible lesson plans and pedagogic activities. To achieve this, it is imperative to deploy multiple strategies to design pedagogic activities and implement them by considering the characteristics of diverse technology-enhanced ways of online or blended learning environments for the delivering of pedagogic instructions in diverse technology-enhanced ways (Huang et al. 2020). It is against this backdrop that the University of Limpopo promptly intervened by training and empowered law lecturers who were hitherto before the pandemic outbreak struggling to use educational technologies to now become capable and competent to discharge their pedagogic responsibilities and as such became technologically savvy in the use of Blackboard collaborate to conduct pedagogy during the COVID-19 pandemic and this will continue as the University has now adopted blended pedagogy where multi-modal is broadly deployed.

\section{Findings and Discussions}

The use of modern-day virtual technologies of all types for pedagogies at the universities are no more an option but a must. It is expected that post-COVID-19; virtual classrooms will be the norm. Proactive 
universities like the University of Limpopo has positioned itself as one of the forerunners in massive deployment and use of innovative technologies of all types to conduct pedagogies. For instance, presently, Blackboard learning system is widely used by both the lecturers and students for pedagogies at the university. It is now the standard as against pre-COVID-19 era where it was optional. It is important to assert that blended combined pedagogies would now be the normal.

To some in the educational sector, especially lecturers, this might be a herculean task and perceived as an additional burden because throughout their academic sojourns, they have been delivering pedagogies face-to-face. Of note, pre-COVID-19, the introduction of virtual teachings at the University of Limpopo was not readily accepted by some lecturers. The good news is that management of the university has broadly intervened by introducing various in-house training to assist and bring those lagging behind up to speed. Undoubtedly, the use of technology is now part and parcel which must be learned as part of the academic career in order to be able to deliver cutting-edge pedagogy.

More importantly, the blended synchronous pedagogic designs have a whole range of different subject areas and various task types that can be supported using rich-media synchronous technologies. For instance, the Blackboard collaborative has learning tools such as the group questioning, evaluation, role-play, collaborative problem solving, submissions of assignments, organizing tests and so on. However, being competent in the use of these tools requires continuous training for both students and lecturers. This point is made against the backdrop that technology is not static. Pursuant to this, the observation of Bower et al., (2014) is apt where they assert that "as technology and bandwidth continue to improve, we may be entering an age of ubiquitous participation, where remote participants may be represented in any classroom via video modelling and mixed/augmented reality as though they were actually in the room. Until that time, teachers will need to leverage the potentials of the available richmedia technologies to unite remote and face-to-face students, employing appropriate strategies in an attempt to mitigate or overcome the constraints. This research provides an evidential basis for designing and optimizing such blended synchronous learning tasks and experiences." Henceforth, training and workshops on innovative technology that would enhance, improve and strengthen pedagogy should be constantly given to students and lecturers including those who work in the tertiary academic environments.

\section{Conclusion}

In South Africa, the educational sector was hardest hit by the COVID-19 pandemic as most pedagogy pre COVID-19 entailed face-to-face in personal contacts. However, the reality is that in the educational sector and in particular tertiary university, the deployment and use of technology for pedagogy is essential. The COVID-19 pandemic prompted the need for the acceleration of the massive deployment and use of modern-day pedagogical technologies for virtual classrooms in the universities. Both law students and law lecturers were mandated to switch from their methods of pedagogy which mostly use face-to-face venue-based method to multi-modal method. Blackboard systems become imperative for pedagogy and widely deployed by University of Limpopo. Conservative law lecturers were trained by the ICT department of the University in order to empower law lecturers in the arts of effective and efficient use of educational technologies for pedagogy. It is contemporary and as such must be embraced widely, effectively and efficiently in conducting pedagogy. However, despite the efforts of educational institutions and the government, the high level of inequality in South Africa, exacerbated by the pandemic is a set back and major concern in the effectiveness of online pedagogy for all students. The pedagogy environment has to be conducive at all times for all students to maintain a high-quality standard education. As such, blended pedagogy might be the most effective form of pedagogy for tertiary institutions South Africa during and post COVID-19. 


\section{References}

Al Lily, A.E.; Ismail, A.F. \& Abunasser, F.M. (2020).Distance education as a response to pandemics: Coronavirus and Arab culture. Retrieved from:https://doi.org/10.1016/j.techsoc.2020.101317.

Azevedo, J.P. Hasan, A. Goldemberg, D. \& Iqbal, S.A. (2020). Simulating the potential impacts of covid-19 school closures on schooling and learning outcomes: A set of global estimates. Retrieved from:https://elibrary.worldbank.org/doi/abs/10.1596/1813-9450-9284.

Badat, S. (2010). The challenges of transformation in higher education and training institutions in South AfricaDevelopment Bank of Southern Africa. Retrieved from: https://ugeb.pw/801825_doc.html.

Bakker. A. \& Wagner, D. (2020). Pandemic: lessons for today and tomorrow? Educational Studies in Mathematics, 104:1-4.

Bauling, A. (2017). Towards a Sound Pedagogy in Law: A Constitutionally Informed Dissertation as Capstone Course in the LLB Degree Programme,20:1-34.

Bonk, R.J.; \& Kefalaki, M. Rudolph, J. Diamantidaki, F. Munro, C.R. Karanicolas, S. Kontoleon, P. \& Pogner, K. (2020). Pedagogy in the Time of Pandemic: From Localisation to Glocalisation. Retrieved from: https://doi.org/10.34097/jeicom_SP_june2020_1 Pages.

Bower, M.; Kenney, J. Dalgarno, B. Lee, M.J.W. \&. Kennedy, G.E. (2014). Patterns and principles for blended synchronous learning: Engaging remote and face-to-face learners in rich-media real-time collaborative activities. Australasian Journal of Educational Technology, 30(3): 261-272.

Bramble, B. (2020). Pandemic Ethics: 8 Big Questions of COVID-19. Bartleby Books.

Brodeur, A.; Gray, D.M. Islam, A. \& Bhuiyan, S. (2020). A Literature Review of the Economics of COVID-19. Retrieved from: https://papers.ssrn.com/sol3/papers.cfm?abstract_id=3636640.

Burden, K.; Kearney, M. Schuck, S. \& Hall, T. (2019). Investigating the use of innovative mobile pedagogies for school-aged students: A systematic literature review. Computers E Education, 138:83-100.

ButleRitchie, D.T. (2002). Situating Thinking like a Lawyer within Legal Pedagogy. Cleveland State Law Review, 50:29-41.

Situating Thinking like a Lawyer within Legal Pedagogy

Callister, P.D. (2003). Beyond training: law librarianship's quest for the pedagogy of legal research education. Law Library Journal, 95:7-23.

Choi, M.; Cristol, D. Gimbert, B. (2018). Teachers as digital citizens: The influence of individual backgrounds, internet use and psychological characteristics on teachers' levels of digital citizenship. Computers $\mathcal{E}$ Education, 121:143-161.

Cornelius-White, J.H.D.; \& Harbaugh, A.P. (2009). Learner-centered instruction: Building relationships for student success. Sage Publication.

Dhawan, S. (2020). Online learning: A panacea in the time of COVID-19 crisis. Journal of Educational Technology Systems, 49(1): 5-22.

Dokur, D. (2008). An evaluation of the use of educational software in Efl classrooms: Teachers' and students' perspectives. Retrieved from: http://libratez.cu.edu.tr/tezler/6839.pdf.

Doyle, O. (2020). COVID-19: Exacerbating Educational Inequalities? Retrieved from: http://publicpolicy.ie/papers/covid-19-exacerbating-educational-inequalities/.

El Zawaidy, H. (2014) Using Blackboard in online learning at Saudi universities: faculty member's perceptions and existing obstacles. Retrieved from: https://platform.almanhal.com/Files/2/54471.

Florian, L. \& Linklater, H. ( 2010). Preparing teachers for inclusive education: using inclusive pedagogy to enhance teaching and learning for all. Cambridge journal of education, 40(4):369-386.

Francescucci, A. \& Foster, M. (2013). The VIRI (Virtual, Interactive, Real-Time, Instructor-Led) Classroom: The Impact of Blended Synchronous Online Courses on Student Performance, Engagement. Canadian Journal of Higher Education, 43(3):78-91.

Häkkinen, P.; Järvelä, S. Mäkitalo-Siegl, K. Ahonen, A. Näykki, P. \& Valtonen T. (2017). Preparing teacherstudents for twenty-first-century learning practices (PREP 21): a framework for enhancing collaborative problem-solving and strategic learning skills. Journal Teachers and Teaching theory and practice, 23(1):25-41.

Hamad, M.M. (2017). Pros \& Cons of Using Blackboard Collaborate for Blended Learning on Students Learning Outcomes. Higher Education Studies, 7(2): 7-16.

Hefzallah, I.M. (2004). The new educational technologies and learning: Empowering teachers to teach and students to learn in the information age. Charles Thomas Publishers, Springfield, Illinois, USA.

Helmer, S.; Eddy, C. \& Eddy, C.L. (2003). Look at me when I talk to you: ESL learners in non-ESL classrooms. Pippin Publishing Company. 
Huang, R.H.; Liu, D.J., Guo, J., Yang, J.F., Zhao, J.H., Wei, X.F., Knyazeva, S., Li, M., Zhuang, R.X., Looi, C.K., \& Chang, T.W. (2020). Guidance on Flexible Learning during Campus Closures: Ensuring course quality of higher education in COVID-19 outbreak. Beijing: Smart Learning Institute of Beijing Normal University.

Huang, R.H.; Liu, D.J., Tlili, A. Yang, J.F. \& Wang, H.H. (2020). Handbook on Facilitating Flexible Learning During Educational Disruption: The Chinese Experience in Maintaining Undisrupted Learning in COVID-19 Outbreak. Beijing: Smart Learning Institute of Beijing Normal University. Retrieved from: http://creativecommons.org/licenses/by-sa/3.o/igo/.

Jaffer, S.; Ng'ambi, D. \& Czerniewicz, L. (2007). The role of ICTs in higher education in South Africa: one strategy for addressing teaching and learning challenges. International Journal of Education and Development using ICT, $3(4): 131-142$.

Jandrić, P.; Hayes, D. Truelove, I. Levinson, P. (2020). Teaching in the Age of Covid-19. Retrieved from: https://link.springer.com/article/10.1007/s42438-020-00169-6.

Jewitt, C.; Bezemer, J. O'Halloran, K. (2016). Introducing multimodality. Routledge Taylor \& Francis.

Kirschner, R. (2020). How COVID-19 Changed the Way Students Experience Learning: A Blending of Remote and Conventional Education. Retrieved from: https://web.wpi.edu/Pubs/E-project/Available/E-project-o71020170937/unrestricted/CovidEdu_IQP_Report_E2o.pdf.

Kuguyo, O.; Kengne, A.P. \& Dandara, C. (2020). Singapore COVID-19 Pandemic Response as a Successful Model Framework for Low-Resource Health Care Settings in Africa? OMICS: A Journal of Integrative Biology, 24(8):470-478.

Lasso, R. (2002). From the Paper Chase to the Digital Chase: Technology and the Challenge of Teaching 21st Century Law Students. Santa Clara Law Review, 43:1-12.

Laurillard, D. (2013). Rethinking university teaching: A conversational framework for the effective use of learning technologies. Antony Rowe Ltd.

Lee, A.; Poch, R. Shaw, M. \& Williams, R. (2012). Engaging Diversity in Undergraduate Classrooms: A Pedagogy for Developing Intercultural Competence: ASHE Higher Education Report, 38(2):1-21.

Lukong, T.E.; Tombari, S.C. Mbome, B.B. Ankinibom, A.C. Fru, N.P. Atong, H.B. Mbi, T.C. \& Juliet, M.E. (2020). Psychological Implications of Covid-19 on Students Learning Outcome at the University of Buea, Cameroon. American Research Journal of Humanities \& Social Science, 3(8):1-14.

Mahaye, N.E. (2020).The Impact of COVID-19 Pandemic on Education: Navigating Forward the Pedagogy of Blended Learning. Retrieved from:Retrieved from:

https://diwqtxtsıxzle7.cloudfront.net/63078073/The_Impact_of_COVID_Corrected-120200424-26604l2qry5.pdf?1587748671=\&response-content-disposition=inline\%3B+filename\%3

Malik, S \& Agarwal, A. (2012). Use of multimedia as a new educational technology tool-A study. Journal of Information and Education Technology, 2(5):468-471.

Mbunge, E. (2020). Effects of COVID-19 in South African health system and society: An

explanatory study. Retrieved from https://doi.org/10.1016/j.dsx.2020.09.016.

McLoughlin, C. \& Lee, M. (2007). Social software and participatory learning: Pedagogical choices with technology affordances in the Web 2.o era. Retrieved from: https://researchbank.acu.edu.au/cgi/viewcontent.cgi?article $=3049$ \& context $=$ fea_pub.

Mertz, E. (2007). The language of law school: learning to" think like a lawyer". Oxford University Press, Oxford, UK.

Mokgokong, C.; Boshielo, A. \& Raphatlelo, L. (2020). Blackboard Learn and Training, University of Limpopo, South Africa.

Oduwole, O.T. (2012). Institutional assessment as an agent of reform: an analysis of Nigerian legal education. Retrieved from: http://citeseerx.ist.psu.edu/viewdoc/download?doi=10.1.1.452.9843\&rep=rep1\&type=pdf.

O'Flaherty, J \& Phillips, C. (2015). The use of flipped classrooms in higher education: A scoping review. The Internet and Higher Education, 25:85-95.

Osmani, S.R. (2020). Coping with COVID-19. Retrieved from: https://bigd.bracu.ac.bd/wpcontent/uploads/2020/o6/Report_Coping-with-COVID-19-The-Case-for-Bangladesh-1.pdf.

Parker, R.; Morris, K. \& Hofmeyr, J. (2020). Education, inequality and innovation in the time of COVID-19. Published by JET Education Services.

Piguillem, F. \& Shi, L. (2020). Optimal COVID-19 quarantine and testing policies. Retrieved from: https://papers.ssrn.com/sol3/papers.cfm?abstract_id=3594243.

Potts, J.A. (2019). Profoundly gifted students' perceptions of virtual classrooms. Gifted child quarterly, 63(1):58-80.

Price, L.; Richardson, J.T.E. \& Jelfs, A. (2007). Face-to-face versus online tutoring support in distance education. Studies in Higher Education, 32(1):1-20. 
Reimers, F.M. (2020). Global Education Innovation Initiative, Harvard Graduate School of Education Andreas Schleicher, Directorate of Education and Skills, Organisation for Economic Co-operation and Development, A framework to guide an education response to the COVID-19 Pandemic of 2020. Retrieved from: https://teachertaskforce.org/sites/default/files/2020-04/A\%2oframework\%2oto\%2oguide\%2oan\%2oeducation \%2oresponse\%2oto\%2othe\%20COVID-19\%2oPandemic\%20of\%202020.pdf.

Sheail, P. (2018). Temporal flexibility in the digital university: full-time, part-time, flexitime. Journal of Distance Education, 39(4): 462-479.

Sife, A.; Lwoga, E. Sanga, C. (2007). New technologies for teaching and learning: Challenges for higher learning institutions in developing countries. International journal of education and Development using ICT, 3(2): 5767.

Sullivan, W.M.; Colby, A. Wegner, J. W. Bond, L. (2007). Educating lawyers: Preparation for the profession of law. John Wiley \& Sons, Inc.

Tabish, S.A. (2020). The COVID-19 pandemic: Emerging perspectives and future trends. Journal of Public Health Research, 9(1):19-26.

TeachThought (2020). Global The Definition Of The Flipped Classroom. Retrieved from: https://www.teachthought.com/learning/the-definition-of-the-flipped-classroom.

Unuth, N. (2020). What Is the Definition of $3 \mathrm{G}$ Wireless Technology? Retrieved from: https://www.lifewire.com/what-is-3g-3426465.

Walsh, F. (2020). Loss and resilience in the time of COVID-19: Meaning making, hope, and transcendence. Family process, 59(3):898-911.

Yamagata-Lynch, L.C. (2014). Blending online asynchronous and synchronous learning. International Review of Research in Open and Distributed Learning, 15(2): 1-284.

Yandell, J. (2020). Learning under Lockdown: English teaching in the time of Covid-19. Journal Changing English Studies in Culture and Education, 27(3):262-269. 